\title{
Calcium intake, calcium bioavailability and bone health
}

\author{
K. D. Cashman* \\ Nutritional Sciences, Department of Food Science, Food Technology \& Nutrition, and Department of Medicine, \\ University College, Cork, Ireland
}

\begin{abstract}
Calcium accounts for $1-2 \%$ of adult human body weight. Over $99 \%$ of total body Ca is found in the teeth and bones. Therefore, in addition to the obvious structural role of the skeleton, it also serves as a reservoir for $\mathrm{Ca}$. Dietary $\mathrm{Ca}$ intake has an important impact on bone metabolism and bone health. Chronic $\mathrm{Ca}$ deficiency resulting from inadequate intake or poor intestinal absorption is one of several important causes of reduced bone mass and osteoporosis. It is vital, therefore, that adequate dietary $\mathrm{Ca}$ is consumed at all stages of life - in early life so that the genetically programmed peak bone mass can be reached and in later adulthood so that the skeletal mass can be maintained and age-related bone loss minimised. Unfortunately, there is wide variation in the estimates of daily $\mathrm{Ca}$ requirements made by different expert authorities. Furthermore, there is evidence that many individuals are not consuming these recommended levels. The consequence of this for bone health will be discussed in the present review. Besides the amount of $\mathrm{Ca}$ in the diet, the absorption of dietary $\mathrm{Ca}$ in foods is also a critical factor in determining the availability of $\mathrm{Ca}$ for bone development and maintenance. Thus, there is a need to identify food components and/or functional food ingredients that may positively influence $\mathrm{Ca}$ absorption in order to ensure that $\mathrm{Ca}$ bioavailability from foods can be optimised. This approach may be of particular value in individuals who fail to achieve the dietary recommended level of Ca.
\end{abstract}

Calcium intake: Calcium absorption

\section{Introduction}

Osteoporosis is a global health problem that will take on increasing significance as people live longer and the world's population continues to increase in number. Dietary composition is an important determinant of the bone mineral density in the growth period, and of the magnitude of the age-related bone mineral loss, in particular among postmenopausal women (Michaelsen et al. 1994). Calcium, in particular, plays an important role in skeletal health (European Commission, 1998). A sufficient intake of Ca and vitamin $\mathrm{D}$ can reduce the risk of fractures in postmenopausal women, and it is likely that a low $\mathrm{Ca}$ intake may affect peak bone mass negatively (Michaelsen et al. 1994). Nonetheless, dietary Ca intakes are below recommended levels in many EU member states (European Commission, 1998), with consequences for bone health and risk of osteoporosis in these populations. The present review will define the principal disease of bone mass (i.e. osteoporosis) as well as considering its epidemiology and risk factors. The review will then focus on the importance of dietary $\mathrm{Ca}$ in bone health, with particular emphasis on the role of $\mathrm{Ca}$ intake and $\mathrm{Ca}$ bioavailability in maintaining optimal skeletal health.

\section{Definition of osteoporosis and osteopenia}

Osteoporosis is defined as a systemic skeletal disease characterised by low bone mass and microarchitectural deterioration of bone tissue, with a consequent increase in bone fragility and susceptibility to fracture (Consensus Development Conference, 1993). Osteopenia is sometimes referred to as borderline low density because there is a loss of bone density, but less than is seen with osteoporosis. For the purposes of clinical diagnosis, a Working Party of the World Health Organisation has redefined osteoporosis and osteopenia according to bone mass, at least for women. Their diagnostic criteria for osteoporosis and osteopenia, based on bone mineral content (BMC) or bone mineral density (BMD) include: normal, within 1 standard deviation (SD) of young adult reference mean for the population; osteopenia, between -1 and $-2.5 \mathrm{SD}$ of the young adult mean; osteoporosis, more than $-2 \cdot 5$ SD below the young adult mean, and established osteoporo-

\footnotetext{
Abbreviations: CPP, casein phosphopeptides; NDO, non-digestible oligosaccharide; PBM, peak bone mass; PTH, parathyroid hormone. Note: For the definition of the terms inulin and oligofructose please refer to the introductory paper (p. S139) and its footnote. *Corresponding author: Professor K. D. Cashman, fax +353 21 4270244, email k.cashman@ucc.ie
} 
sis as the same mass definition but associated with a fragility fracture (World Health Organisation, 1994). Fragility fractures are the hallmark of osteoporosis and are particularly common in the spine, hip and distal forearm, although they can occur throughout the skeleton.

\section{Epidemiology of osteoporosis}

Osteoporotic fractures constitute a major public health problem. Currently, in the US alone, 10 million individuals already have osteoporosis, and a further 18 million more have low bone mass, placing them at increased risk for this disorder (National Institutes of Health, 2000). One in eight EU citizens over the age of 50 years will fracture their spine this year (European Commission, 1998). The estimated remaining lifetime risk of fractures in Caucasian women at the age of 50 years, based on incidence rates in North America is $17.5 \%, 15.6 \%$ and $16 \%$ for hip, spine and forearm respectively; the remaining lifetime risk for any fragility fracture approaches $40 \%$ in women and $13 \%$ in men (Melton et al. 1992). Similar rates have been reported from parts of Europe, although there is a marked variation in the incidence of fractures between countries and regions (Johnell et al. 1992) and even within countries (Elffors et al. 1994). Hip fractures in particular are associated with significant morbidity, necessitating hospital admission for an average of 20-30 days (Johnell et al. 1992). Osteoporosis patients currently occupy 500000 hospital bed nights per year in the European Community (European Commission, 1998). Moreover, they have an overall mortality of $15-30 \%$ (Browner et al. 1996), the majority of excess deaths occurring within the first 6 months after the fracture. Vertebral fractures are also associated with reduced survival (Copper et al. 1993), probably due to clustering of comorbidity which predisposes independently to osteoporosis and premature death. Fractures can also have a profound impact on quality of life, as evidenced by the finding that $80 \%$ of women older than 75 years preferred death to a bad hip fracture resulting in nursing home placement (National Institutes of Health, 2000). Fear, anxiety, and depression are frequently reported in women with established osteoporosis and are likely to be under-addressed when considering the overall impact of this condition (National Institutes of Health, 2000).

The incidence of vertebral and hip fractures increases exponentially with advancing age while that of wrist fractures levels off after the age of 60 years (Compston, 1993). This is of particular concern as it is projected that the number of elderly ( 80 years and older, in whom the incidence of osteoporotic fracture is greatest) in the EU population will grow from 8.9 million and 4.5 million women and men, respectively, in 1995 to 26.4 million and 17.4 million women and men, respectively, in the year 2050 (European Commission, 1998). Because of the increase in incidence rates of osteoporotic fractures with age, the above demographic changes and increasing life expectancy will have a huge impact on the number of fractures that can be expected to occur. For example, the number of hip fractures occurring each year in the EU alone is estimated to rise from current figures of 414000 to 972000 by the year 2050, representing an increase of $135 \%$ (European Commission, 1998). The increase in the number of vertebral fractures occurring each year is not expected to be of the same magnitude as for hip fractures; thus the estimated increase is from current figures of 237000 to 373000 by the year 2050, representing a rise of $57 \%$ (European Commission, 1998).

From an economic perspective, the expenses of hospital care and rehabilitation associated with osteoporotic fractures are a considerable fiscal drain for the health care system, exceeding those of other highly prevalent pathologies of the elderly, such as myocardial infarction (Schurch et al. 1996). Osteoporosis costs national treasuries over 3500 million ECU annually in hospital health care alone (European Commission, 1998).

\section{Risk factors for osteoporosis}

Low bone mineral mass is the main factor underlying osteoporotic fracture (Prentice, 1997). Bone mass in later life depends on the peak bone mass (PBM) achieved during growth and the rate of subsequent age-related bone loss. Bone mineral is laid down throughout childhood, with the most rapid increase occurring during puberty. The deposition continues, at a slower rate, after growth in height has stopped (British Nutrition Foundation, 1989). PBM is achieved in early life (20-35 years), although the exact timing is not certain and may vary between different regions of the skeleton (Teegarden et al. 1995; Institute of Medicine, 1997). From the age of 20 years until approximately 40 years, bone mass is stable in both sexes (Reid \& New, 1997). At older ages, bone is gradually lost from the skeleton in both men and women (Prentice, 1997). For women, there is also a period of about 10-15 years when bone loss (especially at trabecular-rich sites such as the spine or wrist) is accelerated due to oestrogen withdrawal at the menopause, when more than one-third of bone is lost from the skeleton (Compston, 1993). This accelerated rate of loss seen in women, when associated with a low attainment of PBM, leads to excessive risk of future fracture (Reid \& New, 1997).

Bone is a living, dynamic tissue, and is constantly undergoing breakdown and formation as part of the natural process of renewal and repair (Prentice, 1997). Development of maximal bone mass during growth and reduction of loss of bone later in life are the two main strategies of preventing osteoporosis (Weaver, 2000). Consequently, any factor that influences the development of PBM or the loss of bone in middle age will affect later fracture risk. Several factors are thought to influence bone mass. These can be broadly grouped into factors that cannot be modified, such as gender, age, body (frame) size, genetics and ethnicity, and those factors that can be modified, such as hormonal status (especially sex and calciotropic hormone status), lifestyle factors including physical activity levels, smoking and alcohol consumption patterns, and diet. The interaction of these genetic, hormonal, environmental and nutritional factors influences both the development of bone to PBM at maturity and its subsequent loss. It has been suggested that genetic factors probably account for 
up to $80 \%$ of the bone mass variation in the population (Morrison et al. 1994). While diet and lifestyle factors, such as physical activity, may have a smaller influence than genetics on bone mass, these factors are nonetheless important since they are modulators for the achievement of maximum genetic potential peak bone mass as well as the subsequent rate of bone loss and, unlike genotype, they can be modified (Cashman \& Flynn, 1998).

\section{Calcium and bone health}

A large number of macro- and micronutrients have been proposed as possible determinants of bone health and osteoporosis risk. Of the bone-building nutrients, $\mathrm{Ca}$ is the most likely to be inadequate in terms of dietary intake (Weaver, 2000). Therefore, the remainder of the present review focuses only on the impact of $\mathrm{Ca}$ (in particular, $\mathrm{Ca}$ intake and $\mathrm{Ca}$ bioavailability) on bone health.

The adult human body contains about $1200 \mathrm{~g}$ of $\mathrm{Ca}$, which amounts to about $1-2 \%$ of body weight. Of this, $99 \%$ is found in mineralised tissues, such as bones and teeth, where it is present as $\mathrm{Ca}$ phosphate (together with a small component of $\mathrm{Ca}$ carbonate), providing rigidity and structure (Nordin, 1997). The remaining 1\%, found in blood, extracellular fluid (ECF), muscle, and other tissues, plays a role in mediating vascular contraction and vasodilation, muscle contraction, nerve transmission and glandular secretion (Institute of Medicine, 1997).

Calcium is under close homeostatic control with processes such as absorption, excretion and secretion and storage in bone being involved in maintaining the concentration of ionised $\mathrm{Ca}$ in the plasma within a tightly regulated range $(1.1-1.3 \mathrm{mmol} / \mathrm{l}$; British Nutrition Foundation, 1989). This tight regulation of plasma Ca concentration is achieved through a complex physiological system comprising the interaction of the calcitropic hormones, such as parathyroid hormone (PTH), 1,25 dihydroxycholecalciferol $\left(1,25(\mathrm{OH})_{2} \mathrm{D}_{3}\right)$ and calcitonin, with specific target tissues (kidney, bone and intestine) which serve to increase or to decrease the entry of $\mathrm{Ca}$ into the extracellular space. Only in extreme circumstances, such as severe malnutrition or hyperparathyroidism, is the serum ionised $\mathrm{Ca}$ concentration below or above the normal range. The secretion of these hormones is governed wholly, or in part, by the plasma concentration of ionised $\mathrm{Ca}$, thus forming a negative feedback system. PTH and $1,25(\mathrm{OH})_{2} \mathrm{D}_{3}$ are secreted when plasma $\mathrm{Ca}$ is low, while calcitonin is secreted when plasma $\mathrm{Ca}$ is high (British Nutrition Foundation, 1989).

Calcium is required for normal growth and development of the skeleton (National Research Council, 1989a; Nordin, 1997). During skeletal growth and maturation, i.e. until the age of the early twenties in humans, $\mathrm{Ca}$ accumulates in the skeleton at an average rate of $150 \mathrm{mg}$ per day. During maturity, the body - and therefore the skeleton - is more or less in $\mathrm{Ca}$ equilibrium. From the age of about 50 in men and from the menopause in women, bone balance becomes negative and bone is lost from all skeletal sites. This bone loss is associated with a marked rise in fracture rates in both sexes, but particularly in women. Adequate $\mathrm{Ca}$ intake is critical to achieving optimal peak bone mass and modifies the rate of bone loss associated with ageing (National Institutes of Health, 1994).

In recent years, convincing evidence has emerged with respect to effects of dietary $\mathrm{Ca}$ on bone health in all age groups (European Commission, 1998). Intervention and cross-sectional studies have reported a positive effect of $\mathrm{Ca}$ on bone mass in children and adolescents (Kanders et al. 1988; Johnston et al. 1992; Dawson-Hughes, 1996). Välimäki et al. (1994) reported that dietary Ca intake in childhood and adolescence was positively related to bone mineral density in young women. A meta-analysis of thirty-three studies concluded that there was an overall association between $\mathrm{Ca}$ intake and bone mass in premenopausal women (Welten et al. 1995). There is considerable evidence that increasing $\mathrm{Ca}$ intake above that usually consumed in the diet may have benefits for the development and maintenance of bone, and may reduce the risk of osteoporosis in later life (Flynn \& Cashman, 1999). The findings of many of these controlled $\mathrm{Ca}$ intervention trials have been reviewed (Dawson-Hughes, 1991; Institute of Medicine, 1997; Prentice, 1997; Department of Health, 1998).

A number of studies of Ca supplementation in children and adolescents, typically of one to two years duration, have shown that increased $\mathrm{Ca}$ intake is associated with a higher rate of accrual of bone mass (as measured by $\mathrm{BMC}$ or $\mathrm{BMD}$ ) of approximately $1-5 \%$, depending on the skeletal site (Johnston et al. 1992; Lloyd et al. 1993; Andon et al. 1994; Lee et al. 1994; 1996; Bonjour et al. 1997; Cadogan et al. 1997; Dibba et al. 1998; 1999). There is strong consistency in the results of these studies despite the differences in ages of subjects, forms of $\mathrm{Ca}$ used (e.g. as supplements, dairy products or $\mathrm{Ca}$ enriched foods) and in habitual $\mathrm{Ca}$ intake. There is still considerable debate on the meaning of these effects of $\mathrm{Ca}$ on bone. For example, some researchers argue that the increase in bone mass is due to a decrease in bone turnover and is transient and reversible (Department of Health, 1998). In the absence of longitudinal studies of sufficient duration it is not clear whether additional $\mathrm{Ca}$ consumed throughout early life results in increased PBM in adulthood. This question is of great significance since PBM in adulthood is predictive of bone mass, and therefore osteoporosis risk, in later life (Hansen et al. 1991).

Studies of $\mathrm{Ca}$ supplementation in postmenopausal women, typically of one to two years duration, have shown that $\mathrm{Ca}$ cannot prevent bone loss but can reduce the rate of bone loss to some extent. These studies reveal that the effectiveness of $\mathrm{Ca}$ varies by skeletal site, by menopausal age, and with usual $\mathrm{Ca}$ intakes of the study subjects (Institute of Medicine, 1997). For example, supplementation studies indicate that an increase in $\mathrm{Ca}$ intake for women during the first 5 years of menopause (the period of most rapid bone loss) is not effective in retarding bone loss from trabecular regions of the skeleton, including those most vulnerable to osteoporotic fracture (Riis et al. 1987; Dawson-Hughes et al. 1990; Elders et al. 1994). However, reductions in cortical bone loss due to $\mathrm{Ca}$ supplementation are observed during this period (Polley et al. 1987; Riis et al. 1987; Smith et al. 1989; Dawson-Hughes et al. 1990; Elders et al. 1994). 
Women who are more than 5 years past menopause tend to be more responsive to supplemental Ca (Nelson et al. 1991; Reid et al. 1993; Chevalley et al. 1994; Prince et al. 1995), and those with very low $\mathrm{Ca}$ intakes generally gain more from $\mathrm{Ca}$ supplementation than do women with higher usual Ca intakes (Dawson-Hughes et al. 1990; Elders et al. 1994). Trials in women with the highest usual $\mathrm{Ca}$ intakes demonstrate that increasing $\mathrm{Ca}$ intake above $750 \mathrm{mg}$ (Reid et al. 1995), $800 \mathrm{mg}$ (Prince et al. 1995), or $1000 \mathrm{mg}$ (Riis et al. 1987) reduces loss of bone mineral from cortical-rich sites, such as the proximal radius, femoral neck, and total body. Increases in $\mathrm{Ca}$ intake have little effect on spinal-bone mineral in older women (Nelson et al. 1991; Chevalley et al. 1994; Prince et al. 1995).

There is still considerable debate on the significance of the reduction in the rate of bone loss observed in these $\mathrm{Ca}$ supplementation studies. A meta-analysis of $\mathrm{Ca}$ supplementation trials (Mackerras \& Lumley, 1997) confirmed that $\mathrm{Ca}$ supplementation reduces bone loss, but the effects were only significant in the first year of supplementation. Although osteoporosis is usually defined in terms of reduced bone mass, it is the end result, i.e. the greater tendency to sustain fractures, which is of major concern. There have been only a few studies on the effect of Ca supplementation on fracture rates in postmenopausal women. A reduction in vertebral fractures with $\mathrm{Ca}$ supplementation was observed in two studies in which habitual Ca intakes were low (450-620 mg, Chevalley et al. 1994).

Studies of combined supplementation with $\mathrm{Ca}$ and vitamin $\mathrm{D}$ for 1.5-3 years have shown impressive reductions in hip-fracture incidence in elderly women (mean age 84 years) (Chapuy et al. 1992; 1994). More recently, Dawson-Hughes et al. (1997) showed that combined supplementation with $\mathrm{Ca}$ and vitamin $\mathrm{D}$ for 3 years significantly reduced non-vertebral fracture rates in men and women (mean age 71 years). Correction of poor vitamin D status and reduction in serum PTH levels appear to be central to the mechanism of this effect (Prentice, 1997).

The effect of $\mathrm{Ca}$ supplementation on bone turnover in the aforementioned studies is due to the increased $\mathrm{Ca}$ intake increasing plasma $\mathrm{Ca}$, leading to a suppression of plasma PTH and, consequently, the renal production 1,25 $(\mathrm{OH})_{2} \mathrm{D}_{3}$. Reduced serum levels of PTH and 1,25 $(\mathrm{OH})_{2} \mathrm{D}_{3}$ reduce the stimulus for osteoclastic bone resorption (Rubinacci et al.1996).

\section{Consequences of inadequate calcium intakes}

Because of the small metabolic pool of $\mathrm{Ca}$ (less than $0.1 \%$ in the ECF compartment) relative to the large skeletal reserve, for all practical purposes metabolic $\mathrm{Ca}$ deficiency probably never exists, at least not as a nutritional disorder. An inadequate intake or poor intestinal absorption of $\mathrm{Ca}$ causes the circulating ionised $\mathrm{Ca}$ concentration to decline acutely, which triggers an increase in PTH synthesis and release. PTH acts on three target organs to restore the circulating $\mathrm{Ca}$ concentration to normal. At the kidney, PTH promotes the reabsorption of $\mathrm{Ca}$ in the distal tubule. PTH affects the intestine indirectly by stimulating the production of $1,25(\mathrm{OH})_{2} \mathrm{D}_{3}$, which in turn leads to increased $\mathrm{Ca}$ absorption. PTH also induces bone resorption, thereby releasing $\mathrm{Ca}$ into blood. Due to the action of PTH and $1,25(\mathrm{OH})_{2} \mathrm{D}_{3}$ on the target tissues, plasma $\mathrm{Ca}$ levels are restored within minutes to hours (Cashman \& Flynn, 1998; Flynn \& Cashman, 1999).

If, on the other hand, there is a chronic Ca deficiency resulting from a continual inadequate intake or poor intestinal absorption of $\mathrm{Ca}$, circulating $\mathrm{Ca}$ concentration is maintained largely at the expense of skeletal mass, i.e. from an increased rate of bone resorption. This PTHmediated increase in bone resorption is one of several important causes of reduced bone mass and osteoporosis (National Research Council, 1989b; National Institutes of Health, 1994; Institute of Medicine, 1997). The cumulative effect of $\mathrm{Ca}$ depletion on the skeleton over many years contributes to the increasing frequency of osteoporotic fractures with age (Flynn \& Cashman, 1999).

\section{Calcium requirements and recommendations, and prevalence of calcium deficiency}

Given the high proportion of body $\mathrm{Ca}$ which is present in bone and the importance of bone as the major reservoir for $\mathrm{Ca}$, development and maintenance of bone is the major determinant of $\mathrm{Ca}$ needs. Thus, unlike other nutrients, the requirement for $\mathrm{Ca}$ relates not to the maintenance of the metabolic function of the nutrient but to the maintenance of an optimal reserve and the support of the reserve's function (i.e. providing internal structural rigidity needed for locomotion and gravity resisting activity, Heaney, 1997).

Calcium is stored in skeletal tissue as $\mathrm{Ca}$ phosphate crystals embedded in a protein matrix. This composite is laid down as a result of cell-based activity, which, in turn, is determined by the combined effects of genetics and mechanical usage, as well as $\mathrm{Ca}$ availability. Calcium is a threshold nutrient, i.e. at sub-optimal intakes the ability of the organism to store $\mathrm{Ca}$ as bone tissue is limited by the intake of $\mathrm{Ca}$, but increasing $\mathrm{Ca}$ intake above that required as optimal for genetic or mechanical purposes further increases are not stored (Heaney, 1997). Thus, Ca can only be stored as bone and increasing $\mathrm{Ca}$ intake beyond that which produces optimal bone mass will not result in more bone.

Calcium requirements vary throughout an individual's life, with greater needs during the periods of rapid growth in childhood and adolescence, during pregnancy and lactation, and in later life. There are important genetic and environmental influences of $\mathrm{Ca}$ requirements. Genetic influences include such factors as bone architecture and geometry and responsiveness of bone to hormones which mediate the function of bone as the body's $\mathrm{Ca}$ reserve (Heaney, 1997). Environmental influences include factors such as dietary constituents and the degree of mechanical loading imposed on the skeleton in everyday life. Because of their effects on urinary $\mathrm{Ca}$ losses, high intakes of both sodium and protein increase dietary $\mathrm{Ca}$ requirements (Shortt \& Flynn, 1990; Massey \& Whiting, 1996; Heaney, 1997).

There is considerable disagreement on human $\mathrm{Ca}$ 
requirements, and this is reflected in the wide variation in estimates of daily $\mathrm{Ca}$ requirements made by different expert authorities. For example, expert committees in the US, UK and EU have established very different recommendations for Ca intake (European Commission, 1993; Institute of Medicine, 1997; Department of Health, 1998), see Table 1. Much of this divergence arises due to different interpretations of available human $\mathrm{Ca}$ balance data. The higher recommendations in the US derive from defining $\mathrm{Ca}$ requirements based on desirable $\mathrm{Ca}$ retention estimated from human $\mathrm{Ca}$ balance studies, i.e. that which results in the maximum skeletal $\mathrm{Ca}$ reserve (Institute of Medicine, 1997).

Low Ca status as reflected in reduced bone mass appears to be common in western countries. According to recent estimates obtained using WHO diagnostic criteria (based on bone mineral content), approximately 4-6 million older women and 1-2 million older men have osteoporosis in the US (Looker et al. 1997). Because life expectancy in western countries is increasing (it will soon average more than 80 years in the US and the EU), it is anticipated that this disease will affect an even larger proportion of the population in future (Melton et al. 1992). However, while low bone mass may be taken as an estimate of low Ca status, it should be noted that there are a number of contributory factors to this besides dietary $\mathrm{Ca}$ deficiency (e.g. altered hormonal status associated with amenorrhoea or menopause, physical inactivity).

In the absence of reliable indicators of nutritional adequacy for $\mathrm{Ca}$, estimates of $\mathrm{Ca}$ deficiency are based largely on adequacy of dietary intake relative to recommendations. However, this approach is complicated by the lack of agreement between expert groups on recommended $\mathrm{Ca}$ intakes (Table 1). In practice, estimates of the proportion of the population in different countries with inadequate
Ca intake are based on recommended intakes for the individual countries. Using this approach, it has been reported that a significant proportion of some population groups fails to achieve the recommended $\mathrm{Ca}$ intakes in a number of western countries.

For example, about half of adult women and one third of adult men in Germany are consuming $\mathrm{Ca}$ intakes lower than recommended (Heseker et al. 1992; van Dokkum, 1995). Similarly, in Switzerland, a large proportion of adult women fail to achieve the recommended $\mathrm{Ca}$ intake (van Dokkum, 1995). In Ireland, over $50 \%$ of females aged 12 to 18 years fail to achieve the recommended $\mathrm{Ca}$ intake (Irish Nutrition and Dietetic Institute, 1990). In Italy, $50 \%$ of elderly subjects ( $>60$ years) do not meet the recommended allowance for Ca (van Dokkum, 1995). In the Netherlands, a significant proportion $(8-25 \%)$ of adult males and females fail to achieve even $80 \%$ of the recommended allowance for $\mathrm{Ca}$ (van Dokkum, 1995). In the US, most females aged 9 to 18 years and 31 years onwards fail to achieve the recommended $\mathrm{Ca}$ intake (Cleveland et al. 1996). Even in countries where recommended intakes are relatively low inadequate intakes have been reported in some population subgroups. For example, for females in the UK $13-18 \%$ of 14-34-yearolds and $8-15 \%$ of those over 65 years have habitual $\mathrm{Ca}$ intakes less than the lower reference nutrient intake, a level below which intake is almost certainly deficient (Department of Health, 1998).

It should be noted that estimates of $\mathrm{Ca}$ intakes from foods might provide an underestimate of $\mathrm{Ca}$ intake due to under-reporting of food intakes in self-reported food consumption surveys. Furthermore, many surveys do not include the contribution of supplements, medicines or drinking water to total $\mathrm{Ca}$ intakes. Such contributions may be significant for some people.

Table 1. Recommended Ca intakes in the EU, UK and US

\begin{tabular}{|c|c|c|c|c|c|}
\hline \multicolumn{2}{|l|}{ EU PRI (1993)* } & \multicolumn{2}{|c|}{ UK RNI (1998)† } & \multicolumn{2}{|c|}{ US AI (1997)‡ } \\
\hline Age group (years) & $\mathrm{mg} / \mathrm{d}$ & Age group (years) & $\mathrm{mg} / \mathrm{d}$ & Age group (years) & $\mathrm{mg} / \mathrm{d}$ \\
\hline $0.5-1$ & 400 & $0-1$ & 525 & $0-0.5$ & 210 \\
\hline $1-3$ & 400 & $1-3$ & 350 & $0.5-1$ & 270 \\
\hline $4-6$ & 450 & $4-6$ & 450 & $1-3$ & 500 \\
\hline $7-10$ & 550 & $7-10$ & 550 & $4-8$ & 800 \\
\hline $11-14 \mathrm{M}$ & 1000 & $11-14 \mathrm{M}$ & 1000 & $9-13$ & 1300 \\
\hline $15-17 \mathrm{M}$ & 1000 & $15-18 \mathrm{M}$ & 1000 & $14-18$ & 1300 \\
\hline$>18 \mathrm{M}$ & 700 & $11-14 \mathrm{~F}$ & 800 & $19-30$ & 1000 \\
\hline $11-14 \mathrm{~F}$ & 800 & $15-18 \mathrm{~F}$ & 800 & $31-50$ & 1000 \\
\hline $15-17 \mathrm{~F}$ & 800 & $19-50$ & 700 & $51-70$ & 1200 \\
\hline$>18 \mathrm{~F}$ & 700 & $>50$ & 700 & $\begin{array}{l}>70 \\
\text { Pregnancy }\end{array}$ & 1200 \\
\hline Pregnancy & 700 & Pregnancy & $\mathrm{NI}$ & $\leq 18$ & 1300 \\
\hline & & & & $19-50$ & 1000 \\
\hline Lactation & 1200 & Lactation & +550 & Lactation & \\
\hline & & & & $\begin{array}{c}\leq 18 \\
19-50\end{array}$ & $\begin{array}{l}1300 \\
1000\end{array}$ \\
\hline
\end{tabular}

* Population Reference Intakes (PRI) (European Commission, 1993).

†Reference nutrient intake (RNI) (Department of Health, 1998).

$\ddagger$ Adequate intake (AI) (Institute of Medicine, 1997).

Estimates of $\mathrm{Ca}$ requirements refer to males and females unless stated otherwise.

$\mathrm{M}=$ requirements for males; $\mathrm{F}=$ requirements for females. $\mathrm{NI}=$ No increment. 
Improving calcium intakes and calcium bioavailability in the population

The dietary deficiency of Ca identified in some population groups may be addressed in a number of ways. This includes changing eating behaviour at the population level by increasing the consumption of foods which are naturally rich in $\mathrm{Ca}$ (e.g. milk and milk products), $\mathrm{Ca}$ fortification of foods consumed by target groups, or increasing $\mathrm{Ca}$ intakes from $\mathrm{Ca}$ supplements. These may be seen as complementary rather than alternative strategies and each has advantages and disadvantages (Flynn \& Cashman, 1999). For example, it is notoriously difficult to achieve changes in the diet of entire populations, and thus persuading individuals to consume more dairy produce represents a considerable challenge. The use of $\mathrm{Ca}$ supplements can be effective in increasing $\mathrm{Ca}$ intake in individuals who consume them regularly, but it has limited effectiveness at the population level due to the poor compliance with supplement use (Flynn \& Cashman, 1999). Calcium-fortified food products could provide additional choices for meeting $\mathrm{Ca}$ requirements; however, attention should be paid to the selection of products so that they reach the target groups (i.e. those population groups who have the greatest difficulty in meeting $\mathrm{Ca}$ requirements).

Besides the amount of $\mathrm{Ca}$ in the diet, the absorption of dietary $\mathrm{Ca}$ in foods is also a critical factor in determining the availability of $\mathrm{Ca}$ for bone development and maintenance. Thus, there is a need to identify food components and/or functional food ingredients that may positively influence $\mathrm{Ca}$ absorption in order to ensure that $\mathrm{Ca}$ bioavailability from foods can be optimised (Kennefick \& Cashman, 2000).

A number of food constituents have been suggested as potential enhancers of $\mathrm{Ca}$ absorption. Individual milk components, such as lactose, lactulose and casein phosphopeptides have attracted considerable attention. Phosphopeptides derived from the intestinal digestion of casein (casein phosphopeptides, CPP) have been proposed as potential enhancers of $\mathrm{Ca}$ absorption (Mellander, 1950; Kitts \& Yuan, 1973). Berrocal et al. (1989) demonstrated that such phosphopeptides have the capacity to chelate $\mathrm{Ca}$ and to prevent the precipitation of $\mathrm{Ca}$ phosphate salts and suggested that they may help to maintain a high concentration of soluble $\mathrm{Ca}$ in the intestinal lumen. There is some evidence that CPP increase $\mathrm{Ca}$ absorption in rats, minipigs, and chicks (West, 1991). However, there have been only a few studies in humans examining the effect of CPP on Ca absorption. Hansen et al. (1997a) found that $\mathrm{Ca}$ absorption from a high-phytate-containing bread meal was not significantly influenced by the addition $250 \mathrm{mg}$ of CPP in healthy adults but was significantly reduced by the addition of $1000 \mathrm{mg}$. The same group also reported that fractional $\mathrm{Ca}$ absorption was not affected by CPP addition (1000 or $2000 \mathrm{mg}$ ) to a rice-based cereal or from whole-grain cereal, in healthy adults (Hansen et al. 1997b). Furthermore, Heaney et al. (1994) reported that CPP administration was associated with better absorption of co-ingested $\mathrm{Ca}$ by postmenopausal women with low basal absorptive performance. Therefore, the significance of these phosphopeptides for $\mathrm{Ca}$ absorption in humans remains unclear.

Ziegler \& Fomon (1983) showed that Ca absorption in human infants was significantly higher from a soy-based infant formula containing lactose than from a similar formula in which the carbohydrate source was a mixture of starch hydrolysate and sucrose. Enhancement of Ca absorption by lactose has also been shown in rats (Lengemann, 1959; Armbrecht \& Wasserman, 1976; Brommage et al., 1993; Suzuki et al. 1985). However, studies on the effect of lactose on $\mathrm{Ca}$ absorption in human adults generally have failed to demonstrate this effect. Miller, in a review of this area, concluded that it is likely that lactose enhances $\mathrm{Ca}$ absorption in human infants and in rats, while, at levels normally present in milk, lactose does not have a significant effect on $\mathrm{Ca}$ absorption by healthy adults consuming normal diets (Miller, 1989). Recently, Van den Heuvel et al. (1999) reported that a 9-day consumption of lactulose (5 or $10 \mathrm{~g} /$ day) increased Ca absorption in postmenopausal women in a dose-responsive manner.

Emerging evidence has shown that certain non-digestible oligosaccharides (NDOs) can improve $\mathrm{Ca}$ absorption in adolescents and adults. For example, Coudray et al. (1997) fed nine healthy young men a control diet or the same diet supplemented with $40 \mathrm{~g} / \mathrm{day}$ of either inulin or sugar beet fibre for a period of 26 days ( 2 days of control diet followed by 14 days of progressive increase in inulin amount and then 12 days at the maximum inulin consumption) and determined apparent $\mathrm{Ca}$ absorption. They found that upon inulin ingestion, apparent $\mathrm{Ca}$ absorption increased significantly $(P<0.01)$ from $21.3 \%$ to $33.7 \%$ (an increase of $58 \%$ ); ingestion of sugar beet fibre had no effect. In a randomised, double blind, cross-over design study, Van den Heuvel et al. (1999) fed twelve healthy male adolescents (aged 14-16 years) either orange juice supplemented with $5 \mathrm{~g}$ oligofructose or sucrose (control treatment) three times daily for 9 days, after which time, they measured true fractional $\mathrm{Ca}$ absorption by a dual stable isotope technique. An increase of $26 \%$ in true fractional $\mathrm{Ca}$ absorption $(47.8 \%$ with placebo to $60.1 \%$ with oligofructose) was observed upon ingestion of the daily $15 \mathrm{~g}$ supplement of oligofructose. In an earlier study by the same group, a daily supplement of $15 \mathrm{~g}$ of oligofructose had no effect on $\mathrm{Ca}$ absorption in healthy adult men (Van den Heuvel et al. 1998). However, in that study, unlike the latter one, the colonic component of $\mathrm{Ca}$ absorption (a putative target for enhancement by NDO) was not included because the urine collection was limited to $24 \mathrm{~h}$ after isotope administration. In a recent, randomised, double-blind, crossover design study, twenty-nine young adolescent girls (11-14 years, consuming a relatively high $\mathrm{Ca}$ intake, $1500 \mathrm{mg} /$ day) received either $8 \mathrm{~g}$ servings of a mixture of inulin + oligofructose or placebo (sucrose) in a Ca-fortified orange juice daily for 3 weeks. True $\mathrm{Ca}$ absorption was measured using a dual stable isotope method at the end of each 3-week period (Abrams \& Griffin, 2001). A $48 \mathrm{~h}$ urine collection was carried out after isotope administration so as to detect any modulatory effect of the mixture of inulin + oligofructose on the colonic component of $\mathrm{Ca}$ absorption. Consumption of the mixture of inulin + oligofructose resulted in an $18 \%$ 
increase in true fractional $\mathrm{Ca}$ absorption and in an absolute increase in Ca absorption of $90 \mathrm{mg} /$ day (Abrams \& Griffin, 2001).

The findings of these studies strongly suggest that addition of some NDO to food represent an opportunity for increasing the uptake of $\mathrm{Ca}$ present in the diet. However, studies are necessary to prove that the benefits of these ingredients to $\mathrm{Ca}$ absorption persist in the longer term and, importantly, that they can be translated into benefits to bone health.

\section{Conclusion}

Adequate and appropriate nutrition is important for all individuals, but not all follow a diet that is optimal for bone health. Calcium is the specific nutrient most important for attaining PBM and for preventing and treating osteoporosis. However, significant proportions of some population groups fail to achieve the recommended $\mathrm{Ca}$ intakes in a number of western countries. The challenge remaining for interested groups (including nutritionists, health professionals, and the food industry) is to encourage such individuals to meet their $\mathrm{Ca}$ requirements. This task is not an easy one when so few high-Ca foods, except for dairy products, are readily available. Calcium supplements or Ca-fortified foods may be needed by individuals who do not or will not consume Ca-rich foods as recommended in the dietary guidelines of many western countries. In addition, consumption of a functional food, which contains an ingredient (such as lactulose, inulin, oligofructose or both) that may positively influence $\mathrm{Ca}$ absorption, will ensure that the $\mathrm{Ca}$ bioavailability from foods can be optimised.

\section{References}

Abrams SA \& Griffin IJ (2001) Inulin and oligofructose and calcium absorption: Human data. In Proceedings of the $3 \mathrm{rd}$ ORAFTI Research Conference: Recent Scientific Research on Inulin and Oligofructose, pp. 26-27 Belgium: Orafti Active Food Ingredients.

Andon MB, Lloyd T \& Matkovic V (1994) Supplementation trials with calcium citrate malate: evidence in favour of increasing the calcium RDA during childhood and adolescence. Journal of Nutrition 124, 1412S-1417S.

Armbrecht HJ \& Wasserman RH (1976) Enhancement of $\mathrm{Ca}^{2+}$ uptake by lactose in the rat small intestine. Journal of Nutrition 106, 1265-1272.

Berrocal R, Chanton S, Juillerat MA, Scherz JC \& Jost R (1989) Tryptic phosphopeptides from whole casein II. Physicochemical properties related to the solubilization of calcium. Journal of Dairy Research 56, 335-341.

Bonjour JP, Carrie AL, Ferrari S, Clavien H, Slosman D \& Theintz G (1997) Calcium-enriched foods and bone mass growth in prepubertal girls: a randomised, double-blind, placebo-controlled trial. Journal of Clinical Investigation 99, 1287-1294.

British Nutrition Foundation (1989) Calcium. London: British Nutrition Foundation.

Brommage R, Binacua C, Antille S \& Carrié AL (1993) Intestinal calcium absorption in rats is stimulated by dietary lactulose and other resistant sugars. Journal of Nutrition 123, 2186-2194.

Browner WS, Pressman AR, Nevitt MC \& Cummings SR (1996)
Mortality following fractures in older women. The study of osteoporotic fractures. Archives of Internal Medicine 156, $1521-1525$.

Cadogan J, Eastell R, Jones N \& Barker ME (1997) Milk intake and bone mineral acquisition in adolescent girls: randomised, controlled intervention trial. British Medical Journal 315, $1255-1260$.

Cashman K \& Flynn A (1998) Trace elements and bone metabolism. Bibliotheca Nutrition et Dieta 54, 150-164.

Cashman K \& Flynn A (1999) Optimal nutrition - calcium, magnesium and phosphorus. Proceedings of the Nutrition Society 58, 477-487.

Chapuy MC, Arlot ME, Delmas PD \& Meunier PJ (1994) Effect of calcium and cholecalciferol treatment for three years on hip fractures in elderly women. British Medical Journal 308, $1081-1082$.

Chapuy MC, Arlot ME, Duboeuf F, Brun J, Crouzet B, Arnaud S, Delmas PD \& Meunier PJ (1992) Vitamin $\mathrm{D}_{3}$ and calcium to prevent hip fractures in the elderly women. New England Journal of Medicine 327, 1637-1642.

Chevalley T, Rizzoli R, Nydegger V, Slosman D, Rapin CH, Michel J, Vasey H \& Bonjour JP (1994) Effects of calcium supplements on femoral bone mineral density and vertebral fracture rate in vitamin D replete elderly patients. Osteoporosis International 4, 245-252.

Cleveland LE, Goldman JD \& Borrud LG (1996) Data tables: results from USDA's 1994 continuing survey of food intakes by individuals and 1994 Diet and Health Knowledge Survey. Beltsville, MD: Agriculture Research Service, US Department of Agriculture.

Compston J (1993) Osteoporosis. In The Management of Common Metabolic Bone Disorders, pp. 29-62 [G Campbell, J Compston and A Crisp, editors]. Cambridge: Cambridge University Press.

Consensus Development Conference (1993) Diagnosis, prophylaxis and treatment of osteoporosis. American Journal of Medicine 95, 646-650.

Copper C, Atkinson EJ, Jacobsen SJ \& O'Fallon WM (1993) A population-based study of survival following osteoporotic fractures. American Journal of Epidemiology 86, 247-253.

Coudray C, Bellanger J, Castíglia-Delavaud C, Vermorel V \& Rayssignuier Y (1997) Effect of soluble or partly soluble dietary fibres supplementation on absorption and balance of calcium, magnesium, iron and zinc in healthy young men. European Journal of Clinical Nutrition 51, 375-380.

Dawson-Hughes B (1991) Calcium supplementation and bone loss: a review of controlled clinical trials. American Journal of Clinical Nutrition 54, 274S-280S.

Dawson-Hughes B (1996) Calcium insufficiency and fracture risk. Osteoporosis International 3, S37-S41.

Dawson-Hughes B, Dallal GE, Krall EA, Sadowski L, Sahyoun N \& Tannenbaum S (1990) A controlled trial of the effect of calcium supplementation on bone density in post-menopausal women. New England Journal of Medicine 323, 878-883.

Department of Health (1991) Calcium. In Dietary Reference Values for Food Energy and Nutrients for the United Kingdom. Report in Health and Social Subjects no. 41. pp. 150-157. London: HM Stationery Office.

Department of Health (1998) Nutrition and Bone Health with Reference to Calcium and Vitamin D. Dietary Reference Values for Food Energy and Nutrients for the United Kingdom. Report in Health and Social Subjects no. 49. London: HM Stationery Office.

Dibba B, Prentice A, Poskitt EME \& Cole TJ (1998) Calcium supplementation increases the bone mineral status of Gambian children. Proceedings of the Nutrition Society 57, 73A.

Dibba B, Prentice A, Stirling D \& Poskitt EME (1999) Effect of 
calcium supplementation on plasma osteocalcin concentration of Gambian children. Proceedings of the Nutrition Society 58, 61A.

Elders PJM, Lips P, Netelenbos JC, Van Ginkel FC, Khoe E, van der Vijgh WJF \& van der Stelt PF (1994) Long-term effect of calcium supplementation on bone loss in perimenopausal women. Journal of Bone and Mineral Research 9, 938-970.

Elffors I, Allander E, Kanis JA, Gullberg B, Johnell O, Dequeker J, Dilsen G, Gennari C, Lopes Vaz AA \& Lyritis G (1994) The variable incidence of hip fracture in Southern Europe; The Medos study. Osteoporosis International 4, 253-263.

European Commission (1993) Calcium. In Nutrient and Energy Intakes of the European Community. Report of the Scientific Committee for Food (31st series), pp. 136-145, Luxembourg: Official Publications of the European Communities.

European Commission (1998) Report on osteoporosis in the European Community: Action for Prevention. Office for Official Publications for the European Commission, Luxembourg.

Flynn A \& Cashman K (1999) Calcium fortification of foods. In Mineral Fortification of Foods, pp. 18-53 [R Hurrell, editor]. Surrey: Leatherhead Food RA.

Hansen M, Sandström B, Jensen M \& Sørensen SS (1997a) Effect of casein phosphopeptides on zinc and calcium absorption from bread meals. Journal of Trace Elements in Medicine and Biology 11, 143-149.

Hansen M, Sandström B, Jensen M \& Sørensen SS (1997b) Casein phosphopeptides improve zinc and calcium absorption from rice-based but not from whole-grain infant cereal. Journal of Pediatric Gastroenterology and Nutrition 24, 56-62.

Hansen MA, Overgaard K, Riis BJ \& Christiansen C (1991) Role of peak bone mass and bone loss in postmenopausal osteoporosis: 12-year study. British Medical Journal 303, 961-964.

Heaney RP, Saito Y \& Orimo H (1994) Effect of casein phosphopeptides on absorbability of co-ingested calcium in normal postmenopausal women. Journal of Bone Mineral Metabolism 12, 77-81.

Heaney RP (1997) The roles of calcium and vitamin D in skeletal health: an evolutionary perspective. Food, Nutrition and Agriculture 20, 4-12.

Heseker H, Adolf T, Eberhardt W, Hartmann S, Herwig A, Kuber W, Matiakse B, Moch KJ, Schneider R \& Zipp A (1992) Food and nutrient intakes of adults in the German Federal Republic. In VERA-Schriftenriche, vol. 3; pp. 188-189 [W Kubler, HJ Anders, W Heeschen and D Kohlmeier, editors]. Neiderkleen: Fleck Verlag.

Institute of Medicine (1997) Dietary Reference Intakes: Calcium, Magnesium, Phophorus, Vitamin D, and Fluoride. Washington, DC: Food and Nutrition Board, National Academy Press.

Irish Nutrition and Dietetic Institute (1990) Irish National Nutrition Survey. Dublin: INDI.

Johnell O, Gullberg B, Allander E \& Kanis JA (1992) The apparent incidence of hip fracture in Europe: A study of national register sources. Osteoporosis International $\mathbf{2}$ 298-302.

Johnston CC Jr, Miller JZ, Slemenda CW, Reister TK, Hui S, Christian JC \& Peacock M (1992) Calcium supplementation and increases in bone mineral density in children. The New England Journal of Medicine 327, 82-87.

Kanders B, Dempster DW \& Lindsay R (1988) Interaction of calcium nutrition and physical activity on bone mass in young women. Journal of Bone Mineral Research 3, 145-149.

Kennefick S \& Cashman KD (2000) Investigation of an in vitro model for predicting the effect of food components on calcium availability from meals. International Journal of Food Sciences and Nutrition 51, 45-54.

Kitts DD \& Yuan YV (1973) Casein phosphopeptides and calcium bioavailability. Trends in Food Science and Technology 3, 31-35.

Lee WTK, Leung SSF, Leung DMY \& Cheng JCY (1996) A follow-up study on the effects of calcium-supplement withdrawl and puberty on bone acquisition of children. American Journal of Clinical Nutrition 64, 71-77.

Lee WTK, Leung SSF, Wang SH, Xu YC, Zeng WP, Lau J, Oppenheimer SJ \& Cheng JCY (1994) Double-blind, controlled calcium supplementation and bone mineral accretion in children accustomed to a low-calcium diet. American Journal of Clinical Nutrition 60, 744-750.

Lengemann FW (1959) The site of action of lactose in the enhancement of calcium utilization. Journal of Nutrition 69, $23-27$.

Lloyd TM, Andon MB, Rollings N, Martel JK, Landis JR, Demers LM, Eggli DF, Keisekhorst K \& Kulin HE (1993) Calcium supplementation and bone mineral density in adolescent girls. Journal of the American Medical Association 270, $841-844$.

Looker AC, Orwoll ES, Johnston CC Jr, Lindsay RL, Wahner HW, Dunn WL, Calvo MS, Harris TB \& Heyse SP (1997) Prevalence of low femoral bone density in older US adults from NHANES III. Journal of Bone Mineral Research 12, 1761-1768.

Mackerras D \& Lumley T (1997) First- and second-year effects in trials of calcium supplementation on the loss of bone density in postmenopausal women. Bone 21, 527-533.

Massey LK \& Whiting SJ (1996) Dietary salt, urinary calcium and bone loss. Journal of Bone Mineral Research 11, 731-736.

Mellander O (1950) The physiologic importance of the casein phosphopeptide calcium salt, II: peroral calcium dosage of infants. Acta Societae Medica (Uppsala) 55, 247-255.

Melton LJ, Chrischilles EA, Cooper C, Lane AW \& Riggs BL (1992) How many women have osteoporosis? Journal of Bone Mineral Research 7, 1005-1010.

Michaelsen KF, Astrup AV, Mosekilde L, Richelsen B, Schroll M \& Sorensen OH (1994) The importance of nutrition for the prevention of osteoporosis. Ugeskr Laeger 156, 958-960.

Miller DD (1989) Calcium in the diet: Food sources, recommended intakes, and nutritional bioavailability. Advances in Food and Nutrition Research 33, 103-156.

Morrison NA, Qi JC, Tokita A, Kelly PJ, Crofts L, Nguyen TV, Sambrook PN \& Eisman JA (1994) Predicators of bone density from vitamin D receptor alleles. Nature 367, 284-287.

National Institutes of Health (1994) NIH Consensus Statement 12:4. Optimal Calcium Intake. Bethesda, MD: NIH.

National Institutes of Health (2000) Osteoporosis Prevention, Diagnosis, and Therapy. NIH Consensus Development Conference Statement. http://odp.od.nih.gov/consensus/cons/ 111/111_statement.htm

National Research Council (1989a) Recommended Dietary Allowances: 10th edition. Report of the Subcommittee on the Tenth Edition of the RDA. Food and Nutrition Board and the Commission on Life Sciences, Washington, DC: National Academy Press.

National Research Council (1989b) Diet and Health: Implications for Reducing Chronic Disease Risk. Report of the Committee on Diet and Health, Food and Nutrition Board, Commission on Life Sciences. Washington, DC: National Academy Press.

Nelson ME, Fisher EC, Dilmanian TA, Dallal GE \& Evans WJ (1991) A 1-year walking program and increased dietary calcium in post-menopausal women: effects in bone. American Journal of Clinical Nutrition 53, 1304-1311.

Nordin BE (1997) Calcium in health and disease. Food, Nutrition and Agriculture 20, 13-26.

Polley KJ, Nordin BE, Baghurst PA, Walker CJ \& Chatterton BE (1987) Effect of calcium supplementation on forearm bone mineral content in postmenopausal women: a prospective, 
sequential controlled trial. Journal of Nutrition 117, 1929-1935.

Prentice A (1997) Is nutrition important in osteoporosis? Proceedings of the Nutrition Society 56, 357-367.

Prince R, Devine A, Dick I, Criddle A, Kerr D, Kent N, Price R \& Randell A (1995) The effects of calcium supplementation (milk or tablets) and exercise on bone density in postmenopausal women. Journal of Bone and Mineral Research 10, $1068-1075$.

Recker RR, Hinders S, Davies KM, Heaney RP, Stegman MR, Lappe JM \& Kimmel DB (1996) Correcting calcium nutritional deficiency prevents spine fractures in elderly women. Journal of Bone and Mineral Research 11, 1961-1966.

Reid DM \& New SA (1997) Nutritional influences on bone mass. Proceedings of the Nutrition Society 56, 977-987.

Reid IR, Ames RW, Evans MC, Gamble GD \& Sharpe SJ (1995) Long-term effects of calcium supplementation on bone loss and fractures in postmenopausal women: a randomized controlled trial. American Journal of Medicine 98, 331-335.

Reid IR, Ames RW, Evans MC, Gamble GD \& Sharpe SJ (1993) Effect of calcium supplementation on bone loss in post-menopausal women. New England Journal of Medicine 328, 460-464.

Riis B, Thomsen K \& Christiansen C (1987) Does calcium supplementation prevent postmenopausal bone loss? A double-blind, controlled clinical study. New England Journal of Medicine 316, 173-177.

Rubinacci A, Divieti P, Polo RM, Zampino M, Resimini G \& Tenni R (1996) Effect of an oral calcium load on urinary markers of collagen breakdown. Journal of Endocrinological Investigation 19, 719-726.

Schurch M, Rizzoli R, Mermillod B, Vasey H, Michel J \& Bonjour J (1996) A prospective study on socioeconomic aspects of fracture of the proximal femur. Journal of Bone and Mineral Research 11, 1935-1942.

Shortt C \& Flynn A (1990) Sodium-calcium inter-relationships with specific reference to osteoporosis. Nutrition Research Reviews 3, 101-115.

Smith EL, Gilligan C, Smith PE \& Sempos CT (1989) Calcium supplementation and bone loss in middle-aged women. American Journal of Clinical Nutrition 50, 833-842.
Suzuki K, Endo Y, Uehara M, Yamada H, Goto S, Imamura M \& Shiozu S (1985) Effect of lactose, lactulose and sorbitol on mineral utilization and intestinal flora. Journal of the Japanese Society of Nutrition and Food Science 38, 39-42.

Teegarden D, Proulx WR, Martin BR, Zhao J, McCabe GP, Lyle RM, Peacock M, Slemenda C, Johnston CC Jr \& Weaver CM (1995) Peak bone mass in young women. Journal of Bone Mineral Research 10, 711-715.

Välimäki MJ, Kärkkäinen M \& Lamberg-Allardt C, et al. (1994) Exercise, smoking and calcium intake during adolescence and early adulthood as determinants of peak bone mass. British Medical Journal 309, 230-235.

Van den Heuvel EGHM, Schaafsma G, Muys T \& van Dokkum W (1998) Nondigestible oligosaccharides do not interfere with calcium and nonheme-iron absorption in young, healthy men. American Journal of Clinical Nutrition 67, 445-451.

Van den Heuvel EGHM, Muys T, van Dokkum W \& Schaafsma G (1999) Oligofructose stimulates calcium absorption in adolescents. American Journal of Clinical Nutrition 69, 544-548.

van Dokkum W (1995) The intake of selected minerals and trace elements in European countries. Nutrition Research Reviews 8, 271-302.

Weaver CM (2000) The growing years and prevention of osteoporosis in later life. Proceedings of the Nutrition Society 59, 303-306.

Welten D, Kemper HCG, Post GB \& van Staveren W (1995) A meta-analysis of the effect of calcium and bone mass in young and middle aged females and males. Journal of Nutrition 125, 2802-2813.

West DW (1991) Phosphopeptides and calcium absorption. In Proceedings of XXIII International Dairy Congress 2, pp. 1208-1216 Brussels: International Dairy Federation.

World Health Organisation (1994) Assessment of Fracture Risk and its Application to Screening for Postmenopausal Osteoporosis. Technical Report Series 843. Geneva: World Health Organisation.

Ziegler EE \& Fomon SJ (1983) Lactose enhances mineral absorption in infancy. Journal of Pediatric Gastroenterology and Nutrition 2, 288-294. 